\title{
Comparing the impact of spaced instruction and massed instruction in learning collocations among Iranian EFL learners
}

\author{
1Ehsan Namaziandost*, ${ }^{2}$ Choiril Anwar, ${ }^{3}$ Leila Neisi \\ ${ }^{1}$ Department of English, Faculty of Humanities, Shahrekord Branch, Islamic Azad \\ University, Shahrekord, Iran \\ ${ }^{2}$ English Language Education Study Program, Universitas Islam Sultan Agung, \\ Indonesia \\ ${ }^{3}$ Department of Linguistics, Ahvaz Branch, Islamic Azad University, Ahvaz, Iran
}

*Corresponding Author

Email: e.namazi75@yahoo.com

\begin{abstract}
This study compared the impact of spaced instruction and massed instruction on learning collocations among Iranian EFL learners. To do so, 60 Iranian pre-intermediate EFL learners were selected among 90 students based on the results of Oxford Quick Placement Test (OQPT). The selected participants were then non-randomly divided into two equal experimental groups; spaced group and massed group. Afterwards, the researcher measured the participants' collocations knowledge by administering a collocation pre-test. Then, 100 English collocations were instructed to the both experimental groups in the treatment phase of the study. After the instruction, a collocation post-test was administered to both groups and finally the data were analyzed by using paired and independent samples $t$ tests. The obtained results indicated that there was a significant difference between the post-tests of spaced and massed groups. The findings indicated that the spaced group significantly outperformed the massed group $(p<.05)$ on the post-test. The implications of this study can make the teachers aware that teaching through spaced intervals can provide better results than teaching through one massed session.
\end{abstract}

Keywords: Massed instruction; Spacing instruction; Collocation learning

Received:

25 January 2020
Revised:

25 February 2020
Accepted:

28 February 2020
Published:

29 February 2020

\section{INTRODUCTION}

Research in the field of experimental psychology has shown that instruction provided at regularly spaced intervals (spaced distribution) leads to better long-term retention than instruction given in one continuous, uninterrupted session (massed distribution). For example, students spending 30 minutes studying a word list would have better memory of the words if they break the 30 min into three 10-minute sessions spaced over several days or weeks, rather than spending the time in a single 30-minute session. This phenomenon, known as the spacing effect, has been proven in a number of 
learning areas and is considered one of memory research's most valid results (Baddeley, 1997; Namaziandost, Neisi, Kheryadi, \& Nasri, 2019).

The spacing effect theory, first proposed by Ebbinghaus (Ebbinghaus, 1885 ) in 1885 , is that information is best learned and retained when reviewed at spaced intervals rather than in one uninterrupted study session, given a total constant study time. The spacing effect was verified in many learning domains, including mathematics (e.g., Rohrer \& Taylor, 2006), L1 vocabulary acquisition among children (Childers \& Tomasello, 2002; Namaziandost, Sabzevari, \& Hashemifardnia, 2018), recalling facts of physics, and memorizing pictures (e.g., Toppino, 1993), to remember information. The spacing effect was also proven to be effective in performing text tasks (e.g., Seabrook, Brown \& Solity, 2005; Namaziandost, Rahimi Esfahani, \& Ahmadi, 2019). Also, the spacing effect can be effective in developing complex skills beyond rotary memorization. Baddeley and Longman (1978) found the spacing effect to be effective at learning to touch-type participants. In a period of 35 hours, a participant practicing typing for 1 hour per day met the competency targets of the report. Two other groups training for 2 hours a day took approximately 43 hours to achieve the same skill target, and after 50 hours of practice a fourth group practicing for 4 hours a day (two2-hour sessions per day) achieved aim levels.

Rohrer and Taylor (2006) confirmed the significant benefit of using the spacing effect for development of complex mathematical skills. Moulton, Dubrowski, MacRae, Graham, Grober, and Reznick (2006) claimed that teaching a specific surgical technique at spaced intervals (spaced distribution) yielded better practical results than teaching at one massed distribution practice session, as demonstrated in a one-month delayed post-test. Shebilske, Goettl, Corrington, and Day (1999) claimed that by varying practice sessions relative to mass distribution sessions, students learned a more complex computer simulation training challenge better. These results suggest that the methodology of spacing effects go beyond simple rotary memorization of facts, and may help in more complex activities that require the integration of a number of learned abilities.

Two key theoretical accounts of the distributed distribution method are known as uncertainty encoding and processing failure (Greene, 1989; Hashemifardnia, Namaziandost, \& Sepehri, 2018). The theory of encoding variability emphasized that spaced materials are better remembered than massed materials because each presentation is encoded differently in the spaced distribution, thus providing more retrieval signals. Nevertheless, this principle emphasizes the context's function and argues that the sense in which an object is viewed is encoded along with its significance (Anderson \& Bower, 1972). On the other hand, inadequate processing theory (Challis, 1993; Abedi, Namaziandost, \& Akbari, 2019) indicates that as the previous presentation is still too fresh, the second presentation of massed materials does not obtain adequate processing. By contrast, if a subject is presented after some time has passed and some intervening items have been shown, complete processing will be necessary, as the previous presentation will not be as easily available as in the case of massed sequences.

Whereas, several previous studies demonstrated the greater learning ability of spaced teaching in mass education in grammar learning (Miles, 
2014), vocabulary (Miles \& Kwon, 2008; Nakata, 2015; Shakibaei, Shahamat, \& Namaziandost, 2019), and reading (Seabrook, Brown, \& Solity, 2005). Recent evidence indicates that spaced delivery instructions are better than mass distribution instructions in maintaining target language constructs, i.e. when learning is measured after a delayed posttest (Miles, 2014; Nasri, \& Namaziandost, 2019).

Under the name of the spacing effect, investigating the beneficial effects of spacing in learning has been an active area of psychological research. The spacing effect refers to a memory gain by improving recall when learning episodes is scattered over longer periods of time instead of being massaged in a single session (e.g. Cepeda, Pashler, Vul, Wixted, \& Rohrer, 2006; Ziafar \& Namaziandost, 2019a). In general, there is a need to distinguish between two types of repetitions, namely the practice of restudy and retrieval (Goossens, Camp, Verkoeijen \& Tabbers 2014; Namaziandost, Neisi, Mahdavirad, \& Nasri, 2019). Studies in cognitive psychology has shown that the use of recall exercise in the learning phase leads to better memory than restudy (e.g. Roediger \& Karpicke 2006). This process is commonly referred to as the result or study effect of retrieval exercise. The testing effect refers to a memory phenomenon, whereby testing has a more memory-reinforcing effect than restudying.

Regarding the mentioned points, this study aimed to answer the following questions:

RQ 1. Does spacing instruction have any significant effect on Iranian EFL learners' collocation learning?

RQ 2. Does massed instruction have any significant effect on Iranian EFL learners' collocation learning?

\section{METHOD}

\section{Participants}

The participants of this research were selected among 90 Iranian students between the ages of 16 to 17 years old. Sixty participants were chosen among 90 students based on the results of Oxford Quick Placement Test (OQPT). They were selected from two private English language institutes. The English proficiency level of the participants was pre-intermediate. The participants were selected based on convenience non-random sampling method. All the participants were male and native speakers of Persian. The target participants were randomly divided into two equal experimental groups; spacing instruction and massed instruction.

\section{Instruments}

The first instrument which was utilized in the present study to homogenize the participants was the OQPT. It could help the researcher to have a greater understanding of what level (i.e., elementary, pre-intermediate, intermediate) her participants were at. This test has 60 multiple-choice items and based on it the learners whose scores were 0 to 10 were beginners; the learners whose scores were 11 to 17 were considered as breakthrough; the learners whose scores were 18 to 29 were elementary; those learners whose scores were 30 to 39 were pre- intermediate; the students whose scores were 40 to 47 were intermediate; the learners whose scores were 48 to 54 were considered as the 
advanced learners and those whose scores were 55 to 60 were very advanced learners. Based on the results of this test, 60 pre-intermediate students were regarded as the target participants of the current research.

The second instrument for gathering the needed data to answer the research questions of the study was a researcher-made collocation pre-test. This test was given to determine the students' collocation knowledge before receiving the treatment. It consisted of 50 multiple choice items. Internal validity of the questions in the test was established by using a panel of experts from the field of English language teaching. The reliability of the test was computed through using KR-2 1 formula ( $r=0.890)$.

The third instrument which was utilized in this study to ascertain the effects of the treatment on the participants' collocation learning was a researcher-made collocation post-test. The post-test was the modified form of the pre-test; the pre-test was used both as the pre-test and post-test of the study but in the post-test, the order of options and questions were changed to prevent the probable recall of pre-test answers. Since the post-test was the modified version of the pre-test was considered both reliable and valid since the researcher measured the validity and reliability of the pre-test.

\section{Data collection procedure}

After making the participants homogenous, their proficiency level of English collocations knowledge was measured by a collocation pre-test. Afterwards, the students in the experimental groups received the same treatment but in different way. The new collocations were taught to the experimental groups through spacing instruction and massed instruction. In massed class, the collocations were taught during 90 minutes to the students. In fact, 90 minutes were allocated to each session. In spacing class, 90 minutes were divided into three 30 minutes and each session lasted 30 minutes. The spacing class was held three times a week but the massed class was held once a week.

In the treatment phase of the study, the massed distribution group was taught the target words in an intensive 90-minute session, while the spaced distribution group was taught in three short sessions (about 90 minutes. total). The first session lasted for 30 minutes; while the second occurred two days after the initial session (lasted 30 minutes); and the third session took 30 minutes and was held two days after the second session.

The instruction lasted 10 sessions. In the first two sessions, the OQPT and the pre-test were administered respectively; in seven sessions (in each session ten collocations were taught), the students received the treatment, in the tenth session, the post-test was given to the participants of both experimental to measure the effects of the treatment on the students' collocations learning.

\section{Data Analysis}

The descriptive statistics were calculated through using SPSS software, version 25. Firstly, descriptive statistics including means and standard deviation were calculated. Then, to examine the impacts of the treatment on Iranian EFL learners' collocation knowledge, Independent and paired samples t-test were run. 


\section{RESULTS AND DISCUSSION}

It was stated above that 60 pre-intermediate learners were drawn from a larger pool of EFL learners as a result of their scores on the placement test, and were assigned to the two groups of Spaced Instruction Group (SIG) and Massed Instruction Group (MIG). To further ascertain the homogeneity of the two groups in terms of their collocation knowledge before the treatment, their pretest scores were compared via an independent-samples $t$ test:

Table 1. Descriptive statistics for the pretest

\begin{tabular}{lccccc} 
& Groups & N & Mean & Std. Deviation & Std. Error Mean \\
\hline $\begin{array}{l}\text { Prete } \\
\text { st }\end{array}$ & SIG & 30 & 13.2333 & .97143 & .17736 \\
\cline { 2 - 6 } & MIG & 30 & 13.5000 & 1.16708 & .21308 \\
\hline
\end{tabular}

Table 1 shows that the SIG learners' mean score on the pretest equaled 13.2333 and the MIG learners' mean score was 13.5000. To see whether the difference between these two mean scores, and thus the two groups on the pretest, was statistically significant or not, the researcher had to examine the $p$ value under the Sig. (2-tailed) column in the $t$ test table. In this table, a $p$ value less than .05 would indicate a statistically significant difference between the two groups, while a $p$ value larger than .05 indicates a difference which failed to reach statistical significance.

Table 2. Results of independent-samples t-test comparing the pretest scores of

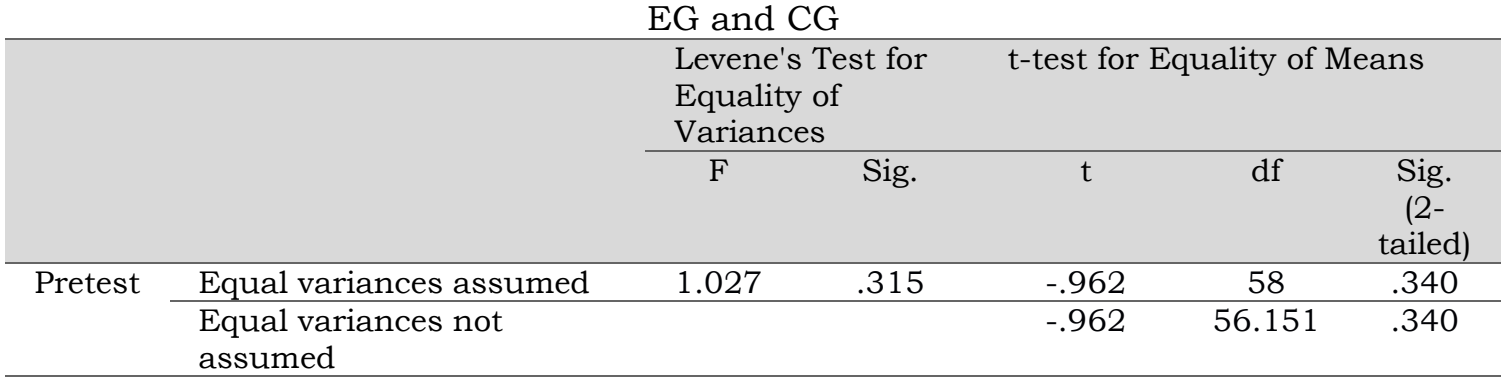

Based in the information presented in Table 2, there was not a statistically significant difference in the pretest scores for SIG $(M=13.2333$, $S D=.97143)$ and MIG $(M=13.5000, S D=1.16708), t(58)=-.962, p=.340$ (two-tailed). This conclusion was made since the $p$ value was larger than the significance level $(p>$.05). Hence, it could be inferred that the learners in the two groups were at the same level of pretest.

The first research question of the study was aimed to find out whether spacing instruction have any significant effect on Iranian EFL learners' collocation learning. To find an answer to this research question, the pretest and posttest scores of the learners in the SIG were compared by means of a paired-samples $t$ test:

Table 3. descriptive statistics for comparing pretest and posttest scores of the SIG

\begin{tabular}{cccccc} 
& & Mean & $\mathrm{N}$ & Std. Deviation & Std. Error Mean \\
\hline Pair 1 & SIG. Post & 15.6167 & 30 & .92553 & .16898 \\
\cline { 2 - 6 } & SIG. Pre & 13.2333 & 30 & .97143 & .17736 \\
\hline
\end{tabular}

It could be observed in Table 3 that the difference between the pretest $(M$ $=13.2333)$ and posttest $(M=15.6167)$ scores of the SIG learners was quite 
substantial (with a mean difference of 2.38333). In order to find out whether this difference between the pretest and posttest scores of the SIG learners was statistically significant or not, the following $t$-test table had to be checked:

Table 4. Results of the paired-samples t-test comparing pretest and posttest scores of the SIG

\begin{tabular}{|c|c|c|c|c|c|c|c|c|c|}
\hline \multicolumn{10}{|c|}{ Paired Samples Test } \\
\hline & & \multicolumn{5}{|c|}{ Paired Differences } & \multirow[t]{3}{*}{$\mathrm{t}$} & \multirow[t]{3}{*}{ df } & \multirow{3}{*}{$\begin{array}{l}\text { Sig. } \\
(2- \\
\text { tailed } \\
\quad)\end{array}$} \\
\hline & & \multirow[t]{2}{*}{ Mean } & \multirow[t]{2}{*}{$\begin{array}{l}\text { Std. } \\
\text { Deviati } \\
\text { on }\end{array}$} & \multirow[t]{2}{*}{$\begin{array}{l}\text { Std. } \\
\text { Error } \\
\text { Mean }\end{array}$} & \multicolumn{2}{|c|}{$\begin{array}{l}\text { 95\% Confidence } \\
\text { Interval of the } \\
\text { Difference }\end{array}$} & & & \\
\hline & & & & & Lower & Upper & & & \\
\hline Pair & SIG. & 2.38 & 1.1271 & .20578 & 1.9624 & 2.8042 & 11.5 & 29 & .000 \\
\hline 1 & $\begin{array}{l}\text { Post - } \\
\text { SIG. } \\
\text { Pre }\end{array}$ & 333 & 2 & & 6 & 1 & 82 & & \\
\hline
\end{tabular}

Table 4 revealed that there was a statistically significant difference between the pretest $(M=13.2333, S D=.97143)$ and posttest $(M=15.6167, S D=$ .92553) scores of the SIG learners since the $p$ value under the Sig, (2-tailed) column was smaller than the significance level (i.e. .000<.05). This indicates that the treatment (using spaced instruction) was effective so far as the collocation knowledge of the Iranian pre-intermediate EFL learners were concerned.

Regarding the second research question of this study, another pairedsamples $t$ test was conducted:

Table 5. Results of descriptive statistics comparing the pretest and posttest scores of

\begin{tabular}{cccccc} 
& \multicolumn{5}{c}{ the MIG learners } \\
\hline \multirow{2}{*}{ Pair 1 } & Mean & $\mathrm{N}$ & $\begin{array}{c}\text { Std. } \\
\text { Deviation }\end{array}$ & Std. Error Mean \\
& MIG. Post & 13.6833 & 30 & 1.22110 & .22294 \\
\cline { 2 - 6 } & MIG. Pre & 13.5000 & 30 & 1.16708 & .21308 \\
\hline
\end{tabular}

As Table 5 shows, the MIG learners obtained the mean scores of 13.5000 on the collocation pretest and 13.6833 on the collocation posttest. In order to determine whether the difference between these two mean scores was statistically significant or not, the researcher needed to consult the pairedsamples $t$ test table (Table 6):

Table 6. Results of paired-samples t-test comparing the pretest and posttest scores of the CG learners

\begin{tabular}{|c|c|c|c|c|c|c|c|c|c|}
\hline \multicolumn{10}{|c|}{ Paired Samples Test } \\
\hline & & \multicolumn{5}{|c|}{ Paired Differences } & \multirow[t]{3}{*}{$\mathrm{t}$} & \multirow[t]{3}{*}{ df } & \multirow{3}{*}{$\begin{array}{l}\text { Sig. } \\
(2- \\
\text { tailed })\end{array}$} \\
\hline & & \multirow[t]{2}{*}{ Mean } & \multirow[t]{2}{*}{$\begin{array}{c}\text { Std. } \\
\text { Deviation }\end{array}$} & \multirow[t]{2}{*}{$\begin{array}{l}\text { Std. } \\
\text { Error } \\
\text { Mean }\end{array}$} & \multicolumn{2}{|c|}{$\begin{array}{l}\text { 95\% Confidence } \\
\text { Interval of the } \\
\text { Difference }\end{array}$} & & & \\
\hline & & & & & Lower & Upper & & & \\
\hline $\begin{array}{l}\text { Pair } \\
1\end{array}$ & $\begin{array}{l}\text { MIG. } \\
\text { Post } \\
- \\
\text { MIG. } \\
\text { Pre }\end{array}$ & .18333 & .35920 & .06558 & .04921 & .31746 & 2.796 & 29 & .09 \\
\hline
\end{tabular}


In Table 6 , the single most important piece of information is the $p$ value under the Sig. (2-tailed) column. This $p$ value should be compared with the pre-specified significance level (i.e., .05) to see if the difference between the pretest and posttest scores had been statistically significant or not. A $p$ value less than .05 would indicate a significant difference between the two sets of scores, while a $p$ value larger than .05 would imply a difference which did not reach statistical significance. As the $p$ value under the Sig. (2-tailed) column in Table 2 was higher than the significance level $(.09>.05)$, it could be construed that the difference between the collocation pretest $(M=13.5000)$ and posttest $(M=13.6833)$ of the MIG learners was not of statistical significance.

\section{CONCLUSION}

After collecting the needed data, they were analyzed through independent and paired samples t-tests. The results indicated that the spacing group improved on their post-test compared to their pre-test. Their scores on the post-test were very better than their scores on the pre-test. This improvement may be the results of spacing instruction.

The findings of this study are in line with Year (2009) who examined the potential role of the spacing effect in foreign language grammar learning. The results revealed that the spaced distribution learners significantly outperformed the massed distribution learners on the elicited production and acceptability judgment tests.

Spacing instruction helped Iranian EFL students to improve their collocation knowledge. In spacing instruction students had more time to rest, had more time to think, and had more time to study; this may lead to the students' collocation development.

The results of this study are supported by Bird (2010) who investigated the effects of explicit L2 grammar instruction via spaced distribution learning. This study revealed that spaced distribution had better performance than the massed group.

Regarding the second research question, after analyzing the data, the findings showed that the massed group did not improve on their post-test compared to their pre-test. Their scores on the pre-test and post-test were almost the same.

The results of this study are compatible with Sobel, Cepeda, and Kapler (2011) who had 39 middle-school children and studied 8 new English words during two sessions with a 1 -week break between study sessions. The children learned the words under two different learning conditions (massed vs. spaced). The results revealed that the recall for spaced items was vastly better than the recall for massed items.

The findings of this study are supported by Lotfolahi and Salehi (2017) who used a new method to find out different schedules of spacing in young EFL learners. To this end, they taught young EFL learners English-Farsi word pairs applying different spacing schedules (massed vs. spaced). The findings indicated that spaced practice produced better long-term retention than massed practice.

The findings imply that spacing instruction enhanced Iranian EFL learners' collocation learning. The findings are in line with previous studies in cognitive psychology (Seabrook et al., 2005) which confirmed the effect of 
spaced distribution instruction in different domains of learning. Moreover, the results are also corroborating some previous studies (e.g., Miles, 2014; Miles \& Kwon, 2008; Namaziandost, Rahimi Esfahani, \& Hashemifardnia, 2018; Rohrer \& Pashler, 2007; Namaziandost, Nasri, Rahimi Esfahani, \& Keshmirshekan 2019) showing that the spaced distribution instruction improved foreign language learning.

Studying information across two or more sessions that are separated (i.e., spaced apart or distributed) in time often produces better learning than spending the same amount of time studying the material in a single session.

The more spaced two objects are, the more likely they will be interpreted differently in the head of the individual according to the encoding variation hypothesis (Anderson \& Bower, 1972). This variability in memory representation, facilitated by the various contexts in which spaced items appear, provides more indication for retrieval. Accordingly, in spaced delivery instructions understanding is preferred. In fact, according to defective processing theory, the first presentation is not easily accessible in scattered sequences at the time of the second presentation, and therefore complete processing of the second presentation is needed (Jacoby, 1978). This processing therefore, in turn, facilitates learning and retention. For addition, when subjects are exposed to two objects concurrently or within a short period of time, they are considered not to give as much energy to these items as when they are provided with appropriate spacing.

In short, the results of this study revealed that instruction about spacing contributes to better learning than instruction about massing. The results showed that spacing community performed better on post-test vocabulary testing, thanks to spacing training. From the findings obtained, it can be concluded that learning through fragmented distribution instruction provides learners a better opportunity to retain a fair amount of knowledge acquired from training until the next opportunity for review arises, either unintentionally through input, intentionally through additional instruction or through the need to use the specific item in voice, reading, or writing (Miles, 2014, p. 421).

\section{REFERENCES}

Abedi, P., Namaziandost, E., \& Akbari, S. (2019). The impact of flipped classroom instruction on Iranian upper-intermediate EFL learners' writing skill. English Literature and Language Review, 5(9), 164-172.

Anderson, J. R., \& Bower, G. H. (1972). Recognition and retrieval processes in free recall. Psychological review, 79(2), 97-123.

Baddeley, A. (1997). Human memory: Theory and practice (revised ed.). Hove: Psychology Press.

Baddeley, A. D., \& Longman, D. J. A. (1978). The influence of length and frequency on training sessions on the rate of learning to type. Ergonomics, 21, 627-635. 
Bird, S. (2010). Effects of distributed practice on the acquisition of second language English syntax. Applied Psycholinguistics,31, 635-650.

Cepeda, N. J., Vul, E., Rohrer, D., Wixted, J. T., \& Pashler, H. (2008). Spacing effects in learning: A temporal ridgeline of optimal retention. Psychological Science, 19, 1095-1102.

Challis, B. H. (1993). Spacing effects on cued-memory tests depend on level of processing. Journal of Experimental Psychology: Learning, Memory, and Cognition, 19(2), 389-396.

Childers, J., \& Tomasello, M. (2002). Two-year-olds learn novel nouns, verbs, and conventional actions from massed or distributed exposures. Developmental Psychology, 38, 697-978.

Ebbinghaus, H. (1885). Memory: A contribution to experimental psychology. New York: Teachers College. Available from: http://psy.ed.asu.edu/w classics/Ebbinghaus/index.htm.

Goossens, N. A., Camp, G., Verkoeijen, P. P., \& Tabbers, H. K. (2014). The effect of retrieval practice in primary school vocabulary learning. Applied Cognitive Psychology, 28, 135-142.

Greene, R. L. (1989). Spacing effects in memory: Evidence for a two-process account. Journal of Experimental Psychology: Learning, Memory, and Cognition, 15(3), 371 -377.

Hashemifardnia, A., Namaziandost, E., \& Sepehri, M. (2018). The effectiveness of giving grade, corrective feedback, and corrective feedback-plus-giving grade on grammatical accuracy. International Journal of Research Studies in Language Learning, 8 (1), 15-27.

Jacoby, L. L. (1978). On interpreting the effects of repetition: Solving a problem versus remembering a solution. Journal of Verbal Learning and Verbal Behavior, 17(6), 649-667.

Lotfolahi, A.R., \& Salehi, H. (2017). Spacing effects in vocabulary learning: Young EFL learners in focus. Cogent Education, 4, 1-10.

Miles, S. W, \& Kwon, C. J. (2008). Benefits of using CALL vocabulary programs to provide systematic word recycling. English Teaching, 63(1), 199-216.

Miles, S. W. (2014). Spaced vs. massed distribution instruction for L2 grammar learning. System, 42(2), 412-428.

Moulton, C. E., Dubrowski, A., MacRae, H., Graham, B., Grober, E., \& Reznick, R. (2006). Teaching surgical skills: What kind of practice makes perfect? Annals of Surgery, 244(3), 400-409.

Nakata, T. (2015). Effects of expanding and equal spacing on second language vocabulary learning. Studies in Second Language Acquisition, 37(4), 677711.

Namaziandost, E., \& Nasri, M., Rahimi Esfahani, F., \& Keshmirshekan M. H. (2019). The impacts of spaced and massed distribution instruction on EFL learners' vocabulary learning. Cogent Education, 6(1): 1661131. https://doi.org/10.1080/2331186X.2019.1661131. 
Namaziandost, E., Neisi, L., Kheryadi, \& Nasri, M. (2019). Enhancing oral proficiency through cooperative learning among intermediate EFL learners: English learning motivation in focus. Cogent Education, 6(1), 115. https://doi.org/10.1080/2331186X.2019.1683933

Namaziandost, E., Neisi, L., Mahdavirad, F., \& Nasri, M. (2019). The relationship between listening comprehension problems and strategy usage among advance EFL learners. Cogent Psychology, 6(1), 1-19. DOI: 10.1080/23311908.2019.1691338.

Namaziandost, E., Rahimi Esfahani, F., \& Ahmadi, S. (2019). Varying levels of difficulty in L2 reading materials in the EFL classroom: Impact on comprehension and motivation. Cogent Education, 6(1), 1-9. https://doi.org/10.1080/2331186X.2019.1615740.

Namaziandost, E., Rahimi Esfahani, F., \& Hashemifardnia, A. (2018). The comparative effect of spacing instruction and massed instruction on intermediate EFL learners' reading comprehension. SAGE Open, 8(4), 1-8. https://doi.org/10.1177/215824401881102.

Namaziandost, E., Sabzevari, A., \& Hashemifardnia, A. (2018). The effect of cultural materials on listening comprehension among Iranian upperintermediate EFL learners: In reference to gender. Cogent Education,5(1), 1-27. https://doi.org/10.1080/2331186X.2018.1560601.

Nasri, M., \& Namaziandost, E. (2019). The impact of topic choice on descriptive writing ability among Iranian advanced EFL learners. International Journal of English Language Studies (IJELS), 1(1), 1-9.

Roediger, III, H. L., \& Karpicke, J. D. (2006). The power of testing memory: Basic research and implications for educational practice. Perspectives on Psychological Science, 1, 181-210.

Rohrer, D., \& Pashler, H. (2007). Increasing retention without increasing study time. Current Directions in Psychological Science, 16, 183-186.

Rohrer, D., \& Taylor, K. (2006). The effects of overlearning and distributed practice on the retention of mathematics knowledge. Applied Cognitive Psychology, 20, 1209-1224.

Seabrook, R., Brown, G. D. A., \& Solity, J. E. (2005). Distributed and massed practice: from laboratory to classroom. Applied Cognitive Psychology, 19, 107-122.

Shakibaei, G., Shahamat, F., \& Namaziandost, E. (2019). The effect of using authentic texts on Iranian EFL learners' incidental vocabulary learning: The case of English newspaper. International Journal of Linguistics, Literature and Translation (IJLLT), 2(5), 422-432

Shebilske, W. L., Goettl, B. P., Corrington, K., \& Day, E. A. (1999). Inter-lesson spacing and task-related processing during complex skill acquisition. Journal of Experimental Psychology: Applied, 5, 413-437.

Sobel, H. S., Cepeda, N. J., \& Kapler, I. V. (2011). Spacing effects in real-world classroom vocabulary learning. Applied Cognitive Psychology, 25, 763767. 
Toppino, T. C. (1993). The spacing effect in preschool children's free recall of pictures and words. Bulletin of the Psychonomic Society, 31, 27-30.

Year, J. (2009). Korean speakers' acquisition of the English ditransitive construction: The role of input frequency and repetition. Unpublished doctoral dissertation, Teacher's College, Columbia University.

Ziafar M., \& Namaziandost, E. (2019). Linguistics, SLA and lexicon as the unit of language. International Journal of Linguistics, Literature and Translation (IJLLT), 2(5), 245-250. 